\title{
A Perfect Storm: formation and potential for preservation of storm beds on the continental shelf
}

Patricia Wiberg

University of Virginia - Charlotteszille, Virginia USA

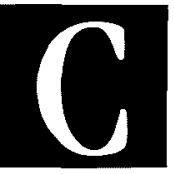

onsider a coastal storm that mobilizes and transports enough sediment on the continental shelf to produce a distinctive deposit in the seabed that escapes significant reworking before it is buried by subsequent sediment accumulation. The characteristics of the deposit, or storm bed, such as thickness, grain-size distribution, size grading, and sedimentary structures, might be expected to reflect the nature of the storm itself and therefore record, in some sense, the conditions that produced it. If this were true, then analysis of the characteristics of storm beds in the marine sedimentary record would reveal important information about the coastal storm environment in the geological past. We might think of an individual storm that leaves a distinctive, permanent, interpretable mark in the sedimentary record as a "perfect" storm.

While easy to imagine, real deposits are seldom like this. Once a storm bed is formed, it is subject to various forms of reworking (Figure 1), including physical reworking from subsequent storms and biological reworking from organisms moving through and ingesting sediment near the bed surface. The potential for preservation of a storm bed depends on the intensity and depth of reworking processes, the thickness of the storm bed, and the rate at which sediment accumulates above the storm bed (Nittrouer and Sternberg, 1981; Wheatcroft, 1990). Net sedimentation at the seafloor moves the storm bed down in the stratigraphic column, away from the zone of most intense reworking. If a significant portion of the bed is buried deeply enough before it is obliterated by physical and biological reworking, then it may remain as a distinctive bed in the long-term sedimentary record.

There are three issues that need to be addressed to determine what type of storm might have the potential to produce a bed that is preserved in the sedimentary record. First, we need to know how the characteristics of a storm bed, e.g. bed thickness, are related to the characteristics of a storm. Then we need to determine the probability of occurrence of these storms so that we know how often storm beds of a given thickness, for example, are formed. Finally, we must evaluate the likelihood that a given storm bed would escape significant biological or physical reworking before it is buried.

Sedimentologists and marine geologists have developed a qualitative understanding of the formation mechanisms for many types of event beds preserved in
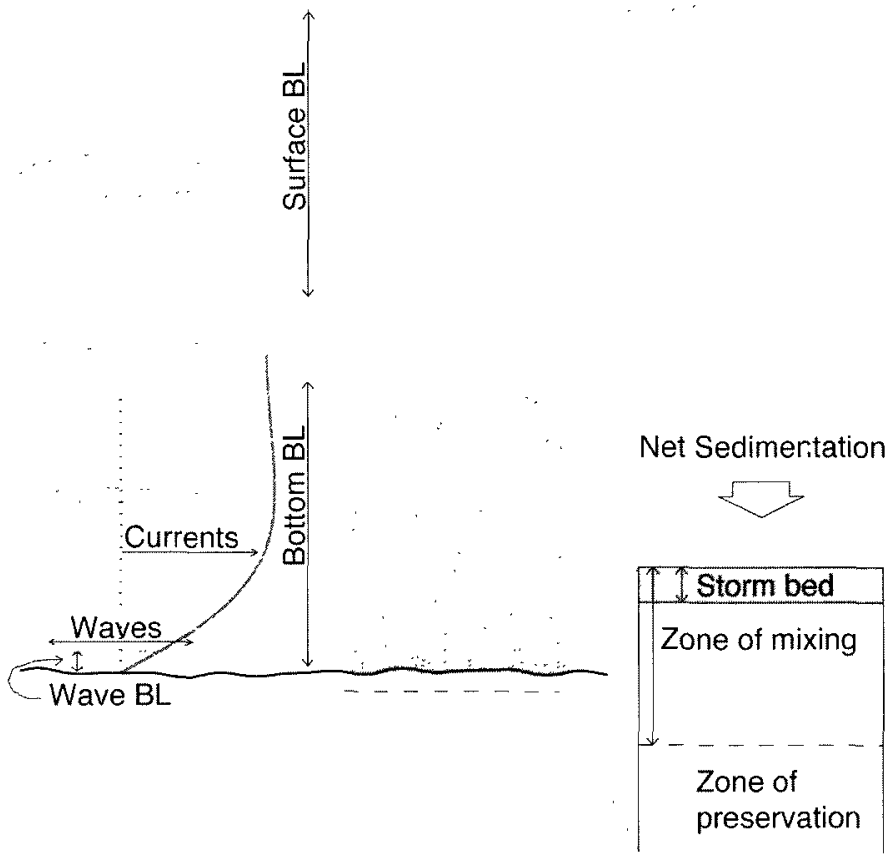

Figure 1. Schematic (not to scale) of bottom boundary layer sediment transport processes responsible for sediment resuspension and storm bed formation. The inset slows the factors affecting the preservation of the resulting storm bed. If net sedinentation moves the storm bed into the zonc of preserzation before biological and physical roworking destroys the recognizable characteristics of the bed, such as a sharp lower contact, textural grading, and sedimentary structures, the bed has a chance of becoming part of the longer-term dipositional record. 

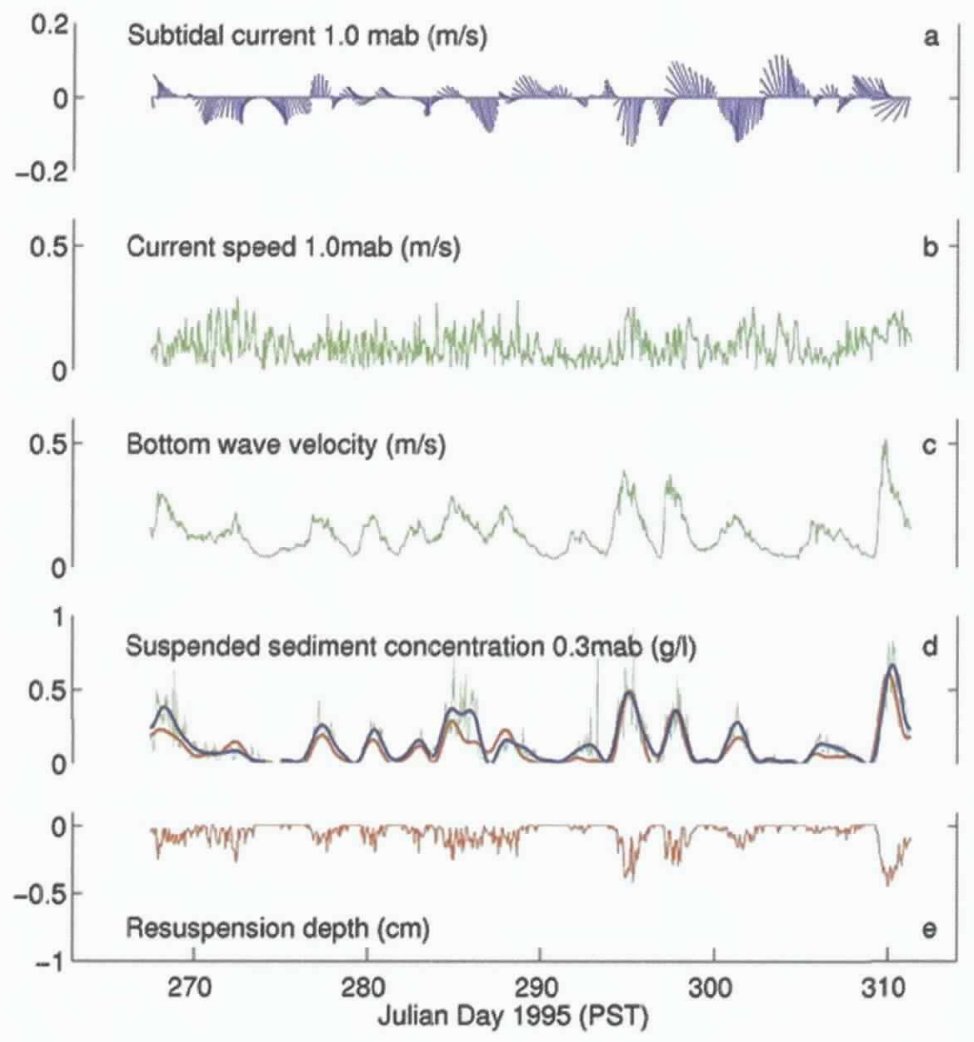

Figure 2. Time series of measured (a) subtidal current velocity 1.0 meters above the bed (mab), (b) hourly current speed $1.0 \mathrm{mab}$, (c) bottom wave velocity, and (d) hourly (green) and subtidally filtered (blue) suspended sediment concentration 0.3 mab at a 60-m site on the Eel shelf during the fall of 1995. The bottom panel shows estimated resuspension depth during the same period determined from calculated suspended sediment volumes divided by the concentration of sediment in the surface layer of the bed (0.3) at the site. Calculated suspended sediment concentrations (subtidally filtered, in red) 0.3 mab are shown in Figure $2 d$ for comparison with measured concentrations.

recent and ancient continental margin deposits through analyses of sediment texture, sedimentary structures, fossils, facies associations and other characteristics (e.g., Dott, 1983; Myrow and Southard, 1996). Quantitative relationships between these deposits and the processes that form them, however, are generally not available. Notable exceptions are turbidites, which have been the subject of a number of modeling and laboratory studies (see, e.g., Middleton, 1993). In this paper, recent advances in field studies and modeling of continental shelf sediment transport are used to provide a quantitative framework for understanding the formation and preservation of storm beds in continental shelf deposits.

\section{Formation of storm beds on the continental shelf}

During the last thirty years or so, a good picture has emerged of sediment transport processes on the continental shelf. Outside the nearshore zone, or where water depths are deeper than 10-20 m, episodic large waves produce the bottom shear stresses necessary to mobilize sediment on the seabed while the coincident currents mix the sediment up into the water column and transport it along and across the shelf (Figure 1). As storms wane and waves die down, bottom stresses decrease and sediment in suspension is redeposited. The redeposited layer typically grades from coarser, less mobile, more rapidly settling sediment at its base to finer, slowly settling sediment at the top. If sand is present in the bed, the redeposited layer may lie above a sandy layer that had been actively transported as bedload during the storm, often in the form of migrating bedforms. The redeposited and surface active layers together form the storm bed.

The thickness of the redeposited layer, termed here the resuspension depth, depends on the amount of sediment that was in suspension and spatial gradients in sediment flux during the storm. Under uniform conditions in which the flow and bed sediment properties are constant along the transport pathway, resuspension depth is given by the volume of sediment in suspension at the peak of the storm divided by the concentration of sediment in the bed (1 - porosity of the bed). The volume in suspension depends on the bottom stress, turbulent mixing profile, and bed sediment characteristics (entrainment threshold, settling rate and porosity). If flow or sediment composition along the transport pathway is nonuniform, the thickness of the redeposited layer can be augmented by net deposition or diminished by net erosion, as a result of divergences in sediment flux. The thickness of the surface active layer is related to the small-scale topography of the bed and the intensity of sediment transport, which also depend on bottom stress and bed sediment characteristics. Coarsening of the surface active layer as fine sediment within it is suspended limits further suspension of fine sediment by armoring the bed surface.

Measurements and models of shelf sediment transport allow us to quantify suspended sediment transport rates and volumes during specific wave and current conditions at a site with known bed properties. For example, an instrumented bottom tripod system has been deployed at a depth of $60 \mathrm{~m}$ on the Eel River shelf (Site S60) during most of each year from fall 1995 to present (Ogston and Sternberg, 1999). The system provides measurements of hourly average currents and suspended sediment concentration $0.3 \mathrm{~m}$ and $1.0 \mathrm{~m}$ above the bed (mab) and of hourly significant bottom wave velocity. Detailed analysis of box core samples provides vertical profiles of near-surface grain size distribution at the measurement site (Drake, 1999). Surficial sediment at the site is predominantly silt, with less than $10 \%$ sand $(>63 \mu \mathrm{m})$.

During the fall of 1995, there were a series of moderate-sized wave events at Site S60, each characterized by an increase in suspended sediment concentration (Figure 2). Bottom wave velocity thresholds for resus- 
pension are between 0.10 and $0.14 \mathrm{~m} / \mathrm{s}$ (Figure 2), corresponding to bed shear stresses of $0.1-0.2 \mathrm{~N} / \mathrm{m}^{2}$. A shelf sediment transport model, such as that employed by Wiberg et al. (1994) and Cacchione et al. (1999) can be used with the measured current, wave, and sediment conditions to calculate suspended sediment profiles throughout the bottom boundary layer. These profiles can be tested against measured suspended sediment concentration (Figure 2d) and can be used to compute suspended sediment volumes and fluxes.

Resuspension depths calculated for the transport events at Site S60 during the fall of 1995 (Figure 2e) are a half-centimeter or less. In contrast, depths of bioturbation tend to be on the order of $10 \mathrm{~cm}$ (Boudreau, 1998) and typical bioturbation rates (e.g. Wheatcroft and Martin, 1996) can remix the upper few centimeters of the bed on the time scale of a week or so (Harris and Wiberg, 1997). Therefore, it is almost certain that beds produced by these relatively small resuspension events will not be preserved.

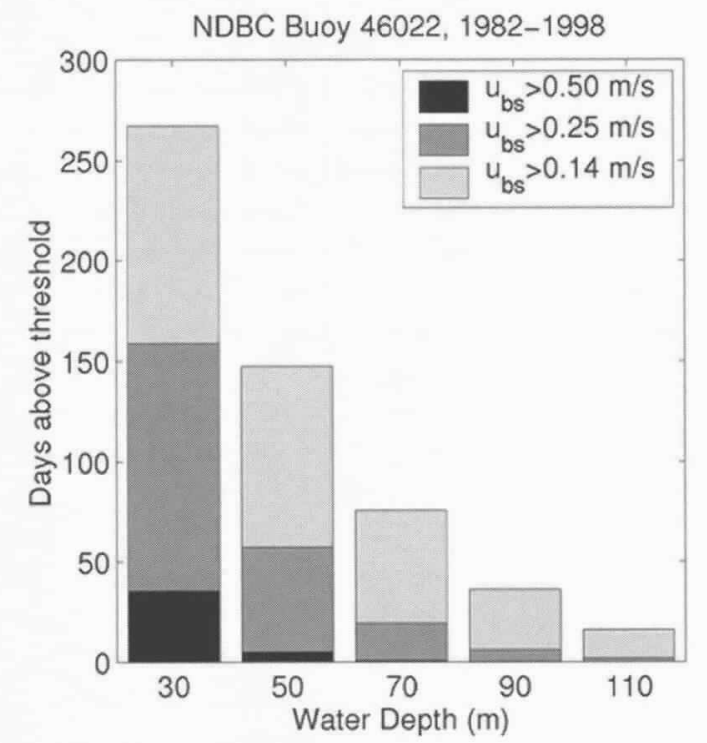

Figure 3. Variations in bottom wave velocity with water depth on the Eel shelf during 1982-1998. Bottom wave conditions were calculated from the hourly surface wave spectral data recorded by NDBC Buoy 46022. Near-bed measurements from the Eel shelf indicate that resuspension occurs when bottom wave velocity exceeds $0.10-0.14 \mathrm{~m} / \mathrm{s}$.

The measurements shown in Figure 2 are from a midshelf site during wave conditions that typically occur a number of times each year. We might expect that larger storms with bigger waves would be more effective at producing thick storm beds and that, for given wave conditions, storm beds would be thicker in shallower water where wave-generated velocities at the bed are larger. We can evaluate this potential, at least on a 10-20 year time frame, using NOAA surface wave buoy data. One of these buoys, located offshore of the Eel margin (NDBC Buoy 46022), has recorded hourly surface wave amplitude spectra beginning in 1982 and continuing until the present with only a few significant interruptions. From these surface spectral data, we can calculate bottom wave orbital velocities, ubs, for depths ranging from the inner shelf, outside the nearshore zone of significant wave transformation, to the shelf break and slope. Bottom wave velocities calculated from surface spectra agree well with values measured by bottom tripods at several sites along the California shelf (e.g. Harris and Wiberg, 1997; Wiberg et al., submitted).

Bottom wave velocities vary across the shelf owing to attenuation of wave orbital motion with depth. In relatively shallow water on the Eel shelf $(30 \mathrm{~m})$, bottom wave velocities exceed threshold conditions for transport of sediment less than $250 \mathrm{~mm}$ in diameter (fine sand) an average of 270 days a year, with a bias toward more energetic wave conditions in the winter compared to the summer (Figure 3). As a result, the bed is almost always in motion during winter months. Migration of long wavelength (order of meters), low amplitude (order of $10 \mathrm{~cm}$ ) bedforms that can be present in the shallower, sandy regions of the shelf (e.g. Cacchione et al., 1994) also contributes to mixing of sediment near the bed surface. Because the bed surface at these shallow depths undergoes almost continuous physical reworking, there is little chance that a substantial part of any specific storm bed will be preserved. In contrast, wave conditions seldom exceed threshold values in water depths over $100 \mathrm{~m}$ on the Eel shelf (Figure 3), and when resuspension does occur, the resulting event beds are so small that there is little chance they will escape bioturbation. Somewhere between these depths, in the range of $50-60 \mathrm{~m}$ on the Eel shelf, the bed is subject to episodic, energetic storm conditions that would seem to provide the optimal conditions for the formation of distinct storm beds. On the Eel shelf, depths of 50-60 m coincide with the transition from a predominantly sandy to a predominantly silty seafloor that marks the boundary between inner and mid-shelf depths.

How large a storm would be required to produce a storm bed at inner to mid-shelf depths that is thick enough to have a chance to escape reworking before it is buried? One approach to answering this question is to calculate suspended sediment concentration profiles and resuspension depths for a range of storm wave conditions, associating a probability of occurrence with each condition (Figure 4).

Suspended sediment concentrations, calculated for a silty-sand bed (characteristic of the inner shelf at a depth of $50 \mathrm{~m}$ on the Eel shelf), show a large response to increasing bottom wave velocity close to the bed, but only a weak response higher in the water column (Figure 4). The relative insensitivity to wave conditions of concentrations a meter or more above the bed in these calculations is partially attributable to using the same current speed in each case (a representative speed of $0.10 \mathrm{~m} / \mathrm{s}, 1 \mathrm{mab})$. More significant, though, are the steep gradients in near-bed bulk density (sediment plus 
water) that form when the difference between bottom wave and current shear velocities becomes large and there is significant sediment in suspension. Steep density gradients tend to inhibit vertical mixing through stratification of the water column, further enhancing near-bed concentration gradients. Near-bed stratification limits the volume of sediment suspended in the bottom boundary layer (Figure $4 \mathrm{~b}$ ) so that resuspension depths in a silty-sand bed associated with bottom wave
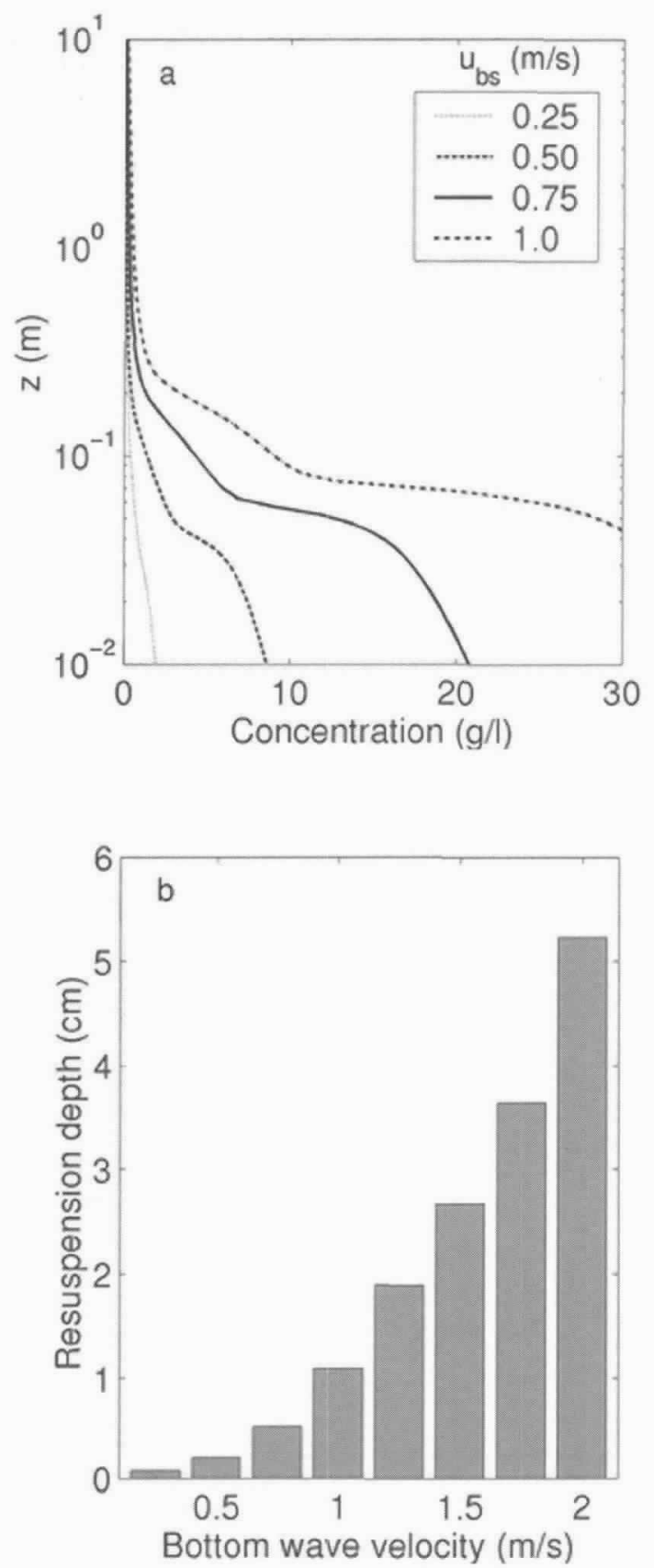

Figure 4. (a) Suspended sediment concentration profiles calculated for a silty-sand bed subject to a range of bottom wave velocities (indicated in legend) and a current speed of $0.10 \mathrm{~m} / \mathrm{s}$. (b) Resuspension depths (volume of sediment in suspension divided by the concentration of sediment in the bed) calculated for bottom wave velocities ranging from $0.25-2.0 \mathrm{~m} / \mathrm{s}$ and a current speed of $0.10 \mathrm{~m} / \mathrm{s}$. velocities up to $2.0 \mathrm{~m} / \mathrm{s}$ and current speeds of $0.10 \mathrm{~m} / \mathrm{s}$ remain considerably less than $10 \mathrm{~cm}$. The same is true for the predominantly silt beds characteristic of midshelf depths (e.g. Site S60), where bed consolidation can also limit suspended sediment volumes.

NDBC wave buoy data can be used to relate bottom wave velocities to surface wave conditions (Figure 5a). For example, the peak recorded wave height of $12 \mathrm{~m}$ on the Eel shelf corresponds to a bottom wave velocity of $1.4 \mathrm{~m} / \mathrm{s}$ at a water depth of $50 \mathrm{~m}$ and $1.2 \mathrm{~m} / \mathrm{s}$ at a depth of $60 \mathrm{~m}$. If these data are extrapolated to higher wave conditions, we find that a wave height of $17-19 \mathrm{~m}$ is required to produce a bottom wave velocity of $2.0 \mathrm{~m} / \mathrm{s}$ at 50-60 m depths, respectively. Return period analysis of wave heights on the Eel shelf based on annual maximum wave heights for a 17 -year period indicate that 17 $19 \mathrm{~m}$ waves have recurrence intervals of 300-1200 years. However, assuming a current speed of $0.10 \mathrm{~m} / \mathrm{s}$, predicted resuspension depths for these extreme wave conditions are still only about $6 \mathrm{~cm}$ at depths of 50-60 m.

Storm bed thickness depends on current as well as wave conditions. Higher current speeds result in higher shear velocities in the bottom boundary layer that increase the volume of sediment that can be maintained in suspension. A few multi-year measurements of currents on the continental shelf are available. For example, the Northern California Coastal Circulation Study (NCCCS; Largier et al., 1993) measured bottom boundary layer currents at five 90-m-deep sites along the northern California shelf during 1988-1989. The highest hourly $(0.65 \mathrm{~m} / \mathrm{s})$ and subtidal $(0.40 \mathrm{~m} / \mathrm{s})$ bottom boundary layer currents (15 mab) were measured on the Eel shelf; currents $1 \mathrm{mab}\left(\mathrm{u}_{\mathrm{c}-1 \mathrm{~m}}\right)$ would be about $35 \%$ smaller assuming a logarithmic velocity profile and a bed roughness of $\sim 0.1 \mathrm{~cm}$. The multi-year STRATAFORM measurements at Site S60 on the Eel shelf (Ogston and Sternberg, 1999) recorded maximum current speeds $1 \mathrm{mab}$ near $0.60 \mathrm{~m} / \mathrm{s}$. Peak currents occur when high subtidal currents coincide with maximum tidal currents. Of the two, only the range of subtidal currents is climatologically driven, with peak recorded near-bed values of $0.40 \mathrm{~m} / \mathrm{s}$ in available data from the Eel shelf.

For water depths less than $100 \mathrm{~m}$ on the Eel shelf, the range of bottom wave velocities (Figure 5) exceeds the range of near-bed current speeds. As water depth decreases, the range of bottom wave velocity increases, thereby increasing the difference between peak waves and currents. This leads to conditions that favor stratification-limited suspended sediment volumes. Under the most extreme combination of recorded (but not simultaneous) hourly waves (ubs $=1.35 \mathrm{~m} / \mathrm{s}$ ) at $50 \mathrm{~m}$ and currents $\left(u_{c-1 m}=0.60 \mathrm{~m} / \mathrm{s}\right)$ on the Eel shelf, calculated resuspension depth is $12 \mathrm{~cm}$. The probability of these occurring simultaneously, however, is much smaller than the probability of either occurring individually, particularly given the poor correlation between waves and currents observed at several sites along the 

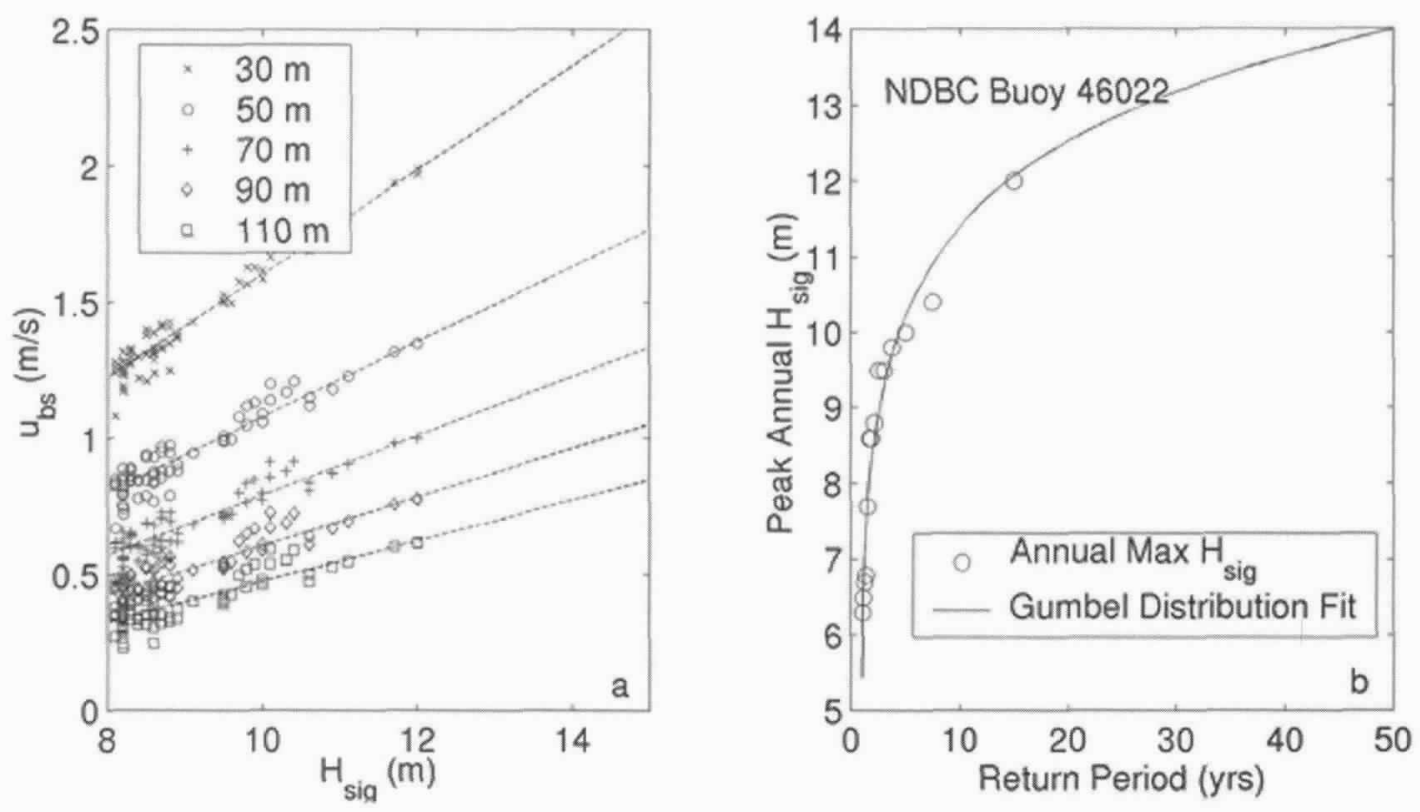

Figure 5. (a) Relationship between surface significant wave height and bottom wave velocity at a range of depths across the Eel shelf based on wave data from NDBC Buoy 46022 during 1982-1998. (b) Return periods for annual maximum significant heights on the Eel shelf determined by fitting a Gumbel distribution to the wave buoy data.

California shelf (e.g. Harris and Wiberg, 1997; Wiberg et al., submitted). Estimated resuspension depth during the largest storm with recorded wave and current conditions on the Eel shelf (December, 1995; see Cacchione et al., 1999) was less than $2 \mathrm{~cm}$ at a 50-mdeep site, despite the high wave and current speeds that characterized this event.

Taken together, available wave and current data and suspended sediment calculations for the Eel shelf suggest that storms capable of producing a $5-\mathrm{cm}$ thick storm bed in water depths of 50-60 $\mathrm{m}$ have recurrence intervals greater than 100 years while those able to produce a 10$\mathrm{cm}$ thick storm bed have recurrence intervals in excess of 1000 years. NDBC wave data indicate that wave conditions on the Eel shelf are more energetic than at other locations on the northern California margin. Therefore, wave recurrence intervals for storm beds of comparable thickness in similar water depths at other sites along the northern California shelf would be longer.

\section{Preservation of storm beds on the continental shelf}

The chances for preservation of a storm bed depend on the competing effects of net sedimentation and physical and biological reworking (Figure 1). In contrast to the episodic nature of physical reworking of storm beds by subsequent sediment transport events, biological reworking persists throughout the year, although biological-mixing intensity can vary seasonally. Detailed analysis of x-radiographs of box-cores collected at a depth of $70 \mathrm{~m}$ on the Eel shelf shows that biological mixing of the bed will destroy an event layer $<5 \mathrm{~cm}$ thick within two years (Wheatcroft, in prep.). By comparison, a sediment transport event with a two-year recurrence interval will rework less than two centimeters of the bed in water depths of $50 \mathrm{~m}$ or more. Time scales of biological mixing increase with bed thickness, and are likely to vary with differences in bed texture. Nevertheless, biological mixing time scales for beds of $5-10 \mathrm{~cm}$ are almost certainly much shorter than recurrence times of storms capable of reworking a bed of comparable thickness at these water depths. Thus, the persistence, intensity, and vertical extent of bioturbation are likely to make it the dominant reworking mechanism operating on storm beds over much of the shelf, with the exception of portions of the inner shelf where large-scale bedforms are active or bottom wave velocities annually exceed values of a few meters/second.

Net sediment deposition during a storm increases the thickness of a storm bed, thereby increasing the chances that a significant part of the bed will escape reworking. Net deposition following a storm increases the likelihood of preservation by moving the storm bed down, away from the zone of most intense reworking. Several processes contribute to net deposition on the continental shelf. Convergence of sediment flux during transport events can produce areas of net sediment accumulation. In particular, decreasing bottom wave velocity with depth, together with a transition from predominantly sandy to silty beds near the inner to mid-shelf transition, can produce net deposition on the mid-shelf. Recently developed cross-shelf transport models suggest that several centimeters of net deposition at mid-shelf depths are possible during a large (10-20 year) storm on the Eel shelf (Zhang et al., 1999; Harris and Wiberg, in press). Pleistocene Eel shelf 
deposits in the Rio Dell Formation include coarse-silt layers, interpreted as mid-shelf storm beds, interbedded with bioturbated clayey silt (Leithold, 1989). Leithold (1989) determined that storm resuspension alone was unlikely to have formed these $5-10 \mathrm{~cm}$ thick layers without net deposition of coarser, inner shelf sediment. Net deposition due to flux convergence represents a redistribution, rather than a net addition, of shelf sediment and is probably limited in its potential to contribute to large, long-term sediment accumulation at any particular site.

River flooding is the primary process introducing new sediment to the shelf. Net deposition on the shelf during a flood varies with river discharge, sediment load, currents, distance from the river mouth, and crossshelf position. Fine-grained deposits on the Eel shelf from floods in 1995 and 1997 reached $5-10 \mathrm{~cm}$ thicknesses at depths around 70-m and distances of $15-20 \mathrm{~km}$ north of the river mouth (Wheatcroft et al., 1996; Sommerfield et al., 1999). These floods are among the 5 largest floods in the 87-year record of Eel River discharge collected at Scotia, CA by the U.S. Geological Survey (USGS). Applying a sediment rating curve based on 21 years (1960-1980) of USGS suspended sediment measurements at Scotia (Sommerfield and Nittrouer, 1999) to the discharge record indicates that almost $25 \%$ of cumulative sediment discharge to the shelf during the 87 -year record occurred during the 5 largest floods.

Based on observed flood-bed thicknesses for the 1995 and 1997 Eel River floods, it is likely that the 5 largest floods combined to produce something like $40-\mathrm{cm}$ of net deposition in the last 50 years near the center of the mid-shelf deposit. This is a considerable fraction of the 100-year average sedimentation rate for the Eel shelf of $0.4 \mathrm{~cm} / \mathrm{y}$, with higher rates at mid-shelf depths (Sommerfield and Nittrouer, 1999). Thus, at least recently, deposition associated with large floods of the Eel River has moved the bed surface layer down in the stratigraphic column by relatively frequent and significant increments. In fact, flood beds are the dominant event beds in box core samples of the upper $50-\mathrm{cm}$ or so of the bed seaward of the sand-silt transition on the Eel shelf (Sommerfield and Nittrouer, 1999). Clay-rich silt layers (average thickness of 1-2 cm) interpreted as flood deposits are also found in the Pleistocene Eel shelf deposits of the Rio Dell Formation (Leithold, 1989).

Both mechanisms of net deposition described above (flux convergence and flood deposition) are episodic and seasonal. In fact, both are potentially linked to the same storms that produce the storm beds in the first place. Analysis of wind and wave data from Buoy 46022 on the Eel shelf and discharge records from the Eel River during 1982-1993 indicates that times of high river discharge are associated with large waves and high, northward wind stress. The coincidence of high discharge and northward (southerly) winds is consistent with the location of the 1995 and 1997 flood beds relative to the Eel River mouth as well as the 100-yeartime-scale locus of sediment accumulation on the Eel margin (Sommerfield and Nittrouer, 1999).

The magnitudes and frequencies of flood deposition compared to storm-bed formation on the Eel shelf suggest that the potential for preservation of a storm bed produced by a moderate to large storm is much greater if it is accompanied by, or just precedes, a large flood. They also suggest that some portion of the storm beds preserved in the geological record of continental margins are likely to have formed by combined storm. and flood action rather than by storms alone. The observed association of storms with floods on the Eel margin makes this even more likely on the Eel shelf.

\section{Conclusions}

Storms that resuspend and transport significant amounts of sediment on the shelf are characterized by high waves and currents. In general, the larger the storm, the larger the waves, and the larger the wave contribution to bottom shear stress relative to that of the currents. This leads to a vertical distribution of stresses in the water column favorable for stratification of the near-bed flow which in turn limits the volume of sediment that can be resuspended from the bed. As a result, it appears to be difficult for a storm, regardless of how large the waves, to resuspend more than a roughly $10-\mathrm{cm}$ thick layer of the bed at depths ranging from $50 \mathrm{~m}$ to the shelf break. In contrast, bioturbation is constantly reworking the upper $10-\mathrm{cm}$ of the bed. Thus storms alone, unless characterized by extremely, and simultaneously, large waves and currents or by large flux gradients that result in areas of high net deposition, appear to produce beds with a very limited potential for preservation in regions of active biological mixing. Preservation potential would be greater on shelves characterized by conditions such as low oxygen levels that inhibit biological activity in the seabed. Observations from the Eel shelf suggest that flood deposition itself does not have such an inhibitory effect (Wheatcroft, in preparation)

The Eel shelf, a region characterized by high waves and currents and large inputs of fluvial sediment, is an ideal location to investigate storm bed preservation and the interplay between storms and floods and the event beds they produce. Evidence from the Eel shelf suggests that episodic flood deposition may be key to long-term preservation of storm beds on shelves with large fluvial sediment supplies. The episodic large floods that dominate net sedimentation on the Eel shelf are less frequent 
than storms, but are capable of creating an order of magnitude thicker event bed at mid-shelf depths than a storm with an equal recurrence interval, at least on time scales of decades. An observed association of large waves with large floods on the Eel shelf suggests that storm resuspension and flood deposition may work in concert during a 'perfect storm' to produce event beds with a high potential for preservation in the long-term marine sedimentary record. Interpretation of these beds requires understanding of flood-depositional processes as well as bottom-boundary-layer processes.

\section{Acknowledgments}

This work has been supported by the U.S. Office of Naval Research STRATAFORM program, Grant No. N00014-91-J-1349. The ideas presented in this paper are the outgrowth of discussions with many individuals, including J. Bourgeois, D. Drake, C. Harris, C. Sherwood, and R. Wheatcroft. Reviews by E. Leithold, C. Sommerfield, R. Wheatcroft, and R. Bjoring improved the paper.

\section{REFERENCES}

Boudreau, B.P., 1998: Mean mixed depth of sediments: The wherefore and the why. Limn. and Oceanogr., 43, 524-526.

Cacchione, D.A., P.L. Wiberg, L. Lynch, J. Irish and P. Traykovski, 1999: Estimates of suspended-sediment flux and bedform activity on the inner portion of the Eel continental shelf. Mar. Geol., 154, 83-97.

Cacchione, D.A., D.E. Drake, J.T. Ferreira and G.B. Tate, 1994: Bottom stress estimates and sand transport on the northern California inner continental shelf. Continental Shelf Research, 14, 1271-1289.

Dott, Robert H., Jr., 1983: Episodic sedimentation How normal is average? How rare is rare? Does it matter? Journ. of Sedimentary Petrology, 53, 5-23.

Drake, D.E., 1999: Temporal and spatial variability of the sediment grain-size distribution on the Eel shelf: the flood layer of 1995. Mar. Geol., 154, 169-182.

Harris, C.K. and P.L. Wiberg, 1997: Approaches to quantifying long-term continental shelf sediment transport with an example from the northern California STRESS mid-shelf site. Continental Shelf Research, 17, 1389-1418.

Harris, C.K. and P.L. Wiberg, in press: A two-dimensional, time-dependent model of suspended sediment transport and bed reworking for continental shelves. Computers and Geosciences.

Largier, J.L., B.A. Magnell and C.D. Winant, 1993: Subtidal circulation over the northern California shelf. Journ. of Geopliys. Res., 98, 18,147-18,179.
Leithold, E.L., 1989: Depositional processes on an ancient and modern muddy shelf, northern California. Sedimentology, 36, 179-202.

Middleton, G.V., 1993: Sediment deposition from turbidity currents. Anmual Review of Earth and Planetary Sciences, 21, 89-114.

Myrow, P.M. and J.B. Southard, 1996: Tempestite deposition. Joum. of Sedimentary Research, Section A, 66, 875-887.

Nittrouer, C.A. and R.W. Sternberg, 1981: The formation of sedimentary strata in an allochthonous shelf environment: the Washington continental shelf. Mar. Geol., 42, 201-232.

Ogston, A.S. and R.W. Sternberg, 1999: Sediment-transport events on the northern California continental shelf. Mar. Geol., 154, 69-82.

Sommerfield, C.K. and C.A. Nittrouer, 1999: Modern accumulation rates and sediment budget for the Eel shelf: a flood-dominated depositional environment. Mar. Geol., 154, 227-241.

Sommerfield, C.K., C.A. Nittrouer and C.R. Alexander, 1999: Be as a tracer of flood sedimentation on the northern California continental margin. Continental Shelf Research, 19, 335-361.

Wheatcroft, R.A., 1990: Preservation potential of sedimentary event layers. Geology, 18, 843-845.

Wheatcroft, R.A. and W.R. Martin, 1996: Spatial variation in short-term $\left({ }^{2.34} \mathrm{Th}\right)$ sediment bioturbation intensity along an organic-carbon gradient. Journ. of Marine Research, 54, 763-792.

Wheatcroft, R.A., J.C. Borgeld, R.S. Born, D.E. Drake, E.L. Leithold, C.A. Nittrouer and C.K. Sommerfield, 1996: The anatomy of an oceanic flood deposit. Oceanography, 9, 158-162.

Wheatcroft, R.A., in preparation: Factors controlling the preservation of flood layers of the northern California shelf.

Wiberg, P.L., D.E. Drake and D.A. Cacchione, 1994: Sediment resuspension and bed armoring during high bottom stress events on the northern California inner continental shelf: measurements and predictions. Continental Shelf Recearch, 14, 1191-1219.

Wiberg, P.L., C.K. Harris and M. Noble, submitted: The sediment transport environment of the Palos Verdes shelf. Continental Shelf Research.

Zhang, Y., D.J.P Swift, S. Fan, A.W. Niederoda and C.W. Reed, 1999: Two-dimensional numerical modeling of storm deposition on the northern California shelf. Mar. Geol., 154, 155-167. 